\title{
雑音に埋もれた信号のオンライン早期検出に 対する一方法
}

\author{
砂 原 善 文*大住 晃*.安 達 良 規*
}

An On-Line Method for Early Decision-Making of Signals in Random Noise

Yoshifumi Sunahara*, Akira OHSUmi* and Yoshinori AdAchi*

The purpose of this paper is to present a new approach to an early decision-making for detecting the signal in random noise by focussing our attention on the initial time estimate when the signal to be detected is applied.

The problem is mathematically stated within the framework of Itô stochastic calculus. The key notion of early decision-making presented here is an application of the multiple hypothesis testing which leads us to compute the likelihood-ratio function. Aspects of the procedure and numerical experiments are also shown by processing real data.

\section{1. 緒言および問題の記述}

Fig. 1 に示したような 1 周期信号波形

$$
s(t)=-A \sin \left(\frac{2 \pi}{T_{0}} t-\phi\right), \phi: \text { 未知不確定位相 }
$$

を不規則観測データから抽出する信号検定問題に対 して，著者らはすでにひとつの信号検出法を確立し $た^{1)}{ }^{2)}$. その方法は，時々刻々取得した観測データか ら対数尤度比関数を計算し, その見本過程が Fig. 1 に 示すように信号波形の通過完了時において最大ピーク を示すという事実に着目するととによって，信号の存 在を決定していた. しかしての方法では，信号の通過 完了時において初めて信号波形の存在が確認されるこ とになり，それより早期に信号検出を遂行したいとい う要請に対しては効果的ではない. そてで本論文では, 信号 $s(t)$ の位相 $\phi$ を未知確定位相とするよりむ,その 初期時刻が未知であるとし，従来の方法より早期に信 号の存在を検出するためのアルゴリズムを確立する.

†第 7 回制御理論シンポジウムで発表（昭 53.5）

* 京都工芸緎維大学工芸学部 京都市左京区松ヶ崎御所海道 町

* Faculty of Polytechnic Sciences, Kyoto Institute of Technology, Kyoto

(Received July 2, 1979)

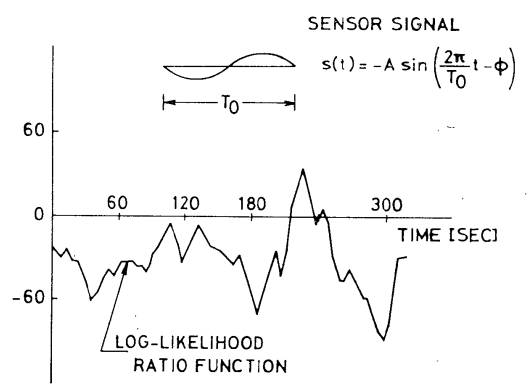

Fig. 1 Representative sample run of the modified log-likelihood ratio function stated in Ref. 1

まず(1)式に代わって，信号を

$$
s\left(t, \tau_{0}\right)=\left\{\begin{aligned}
-A & \sin \frac{2 \pi}{T_{0}}\left(t-\tau_{0}(\omega)\right), \\
t & \in\left[\tau_{0}(\omega), \tau_{0}(\omega)+T_{0}\right] \\
0, & t \notin\left[\tau_{0}(\omega), \tau_{0}(\omega)+T_{0}\right]
\end{aligned}\right.
$$

と表現するととにする. ただし， $\tau_{0}(\omega)$ は検出されるべ き信号の未知不確定初期時刻であり, 振幅 $A$ および周 期 $T_{0}$ は既知，また $\omega$ は見本空間 $\Omega$ の生成点である.

さて, $y(t)$ をスカラー観测過程, $\eta(t)$ を

$$
d \eta(t)=B \eta(t) d t+d v(t), \quad \eta(0)=0
$$

によって創成されるスカラ一雑音過程とする.ただ し， $v(t)$ は分散 $R$ をむつ Brown 運動過程であり， $B$ およびRは既知であるすのとする，乙のとき，

$$
\begin{array}{ll}
H^{1}: y(t)=s\left(t, \tau_{0}\right)+\eta(t) & \text { (信号あり) } \\
H^{0}: y(t)=\eta(t) & \text { (信号なし) }
\end{array}
$$

という仮説を設定し，取得された観測データ $Y_{0}{ }^{t}=\{y$ $(\tau), 0 \leq \tau \leq t\}$ に基づいて，仮説 $H^{1}, H^{0}$ のいずれを 受容するかを決定するということにすれば, 従来決定 が下されていた信号波形の通過完了時刻 $\left(\tau_{0}(\omega)+T_{0}\right)$ より早く決定する問題として捉えることができる.

(4. a), (4. b) 式で記述される仮説検定問題に対し ては，よく知られているように， $\Lambda_{0}(t) \triangleq p\left\{Y_{0}{ }^{t} \mid H^{1}\right\} /$ $p\left\{Y_{0}{ }^{t} \mid H^{0}\right\}$ によって定義される尤度比関数の計算に 
㷌着されるのであるが, $\tau_{0}(\omega)$ という未知不確定パラ メータの存在により仮説 $H^{1}$ は複合仮説となり, この $\Lambda_{0}(t)$ の計算には通常未知パラメータ $\tau_{0}(\omega)$ の確率密 度関数を必要とする ${ }^{3)}$. しかしながら，(2)式のよう な信号波形の存在に対しては，何ら先験的情報がない のが普通であるから，てのままでは $\Lambda_{0}(t)$ の計算は実 行できない. そこで本論文では，次章に抽いて述べる ように, 複合仮説 $\left(H^{1}, H^{0}\right)$ を多值単純仮説に変換し て問題を解決するととにする.

\section{2. 尤度比関数と閾值}

\section{1 尤度比関数}

$\left\{t_{i} ; i=0,1, \cdots\right\}$ を $0=t_{0}<t_{1}<t_{2}<\cdots$ という離散時 刻とし, 各区間 $\left[t_{i}, t_{i+1}\right]$ は信号波形の周期 $T_{0}$ に比 べて十分に小さいむのとする. このとき，現在時刻 $t$ が, $t_{k}<t \leq t_{k+1}$ であるとき，仮説 $\left(H^{1}, H^{0}\right)$ に代わっ $\tau$,

$$
\begin{aligned}
& H_{i}: y(\tau)=s_{i}(\tau)+\eta(\tau) \quad(i=0,1, \cdots, k) \\
& H_{-1}: y(\tau)=\eta(\tau)
\end{aligned}
$$

を設定する，ただし， $0 \leq \tau \leq t$ であり，

$$
s_{i}(\tau)=\left\{\begin{aligned}
-A \sin & \frac{2 \pi}{T_{0}}\left(\tau-t_{i}\right), \\
\tau & \in\left[t_{i}, t_{i}+T_{0}\right] \\
& \tau \notin\left[t_{i}, t_{i}+T_{0}\right]
\end{aligned}\right.
$$

である. 仮説 $H_{-1}$ は時間区間 $[0, t]$ には信号は存在 しないという仮説であり，また $H_{i}$ は時刻 $\tau_{0}(\omega)=t_{i}$ から信号が存在するという仮説である．とのように， 未知パラメータ $\tau_{0}(\omega)$ を含んだ複合仮説検定問題 $\left(H^{1}, H^{0}\right)$ を単純仮説検定問題 $\left(H_{i}, H_{-1}\right)$ 飞変換する ことによって, 未知不確定初期時刻 $\tau_{0}(\boldsymbol{\omega})$ の推定をつ ぎのように実行するととにする.

(5. a )，(5. b) 式によって記述される仮説検定に対 する尤度比関数を

$$
\Lambda\left(t, t_{i}\right) \triangleq \frac{p\left\{Y_{0}{ }^{t} \mid H_{i}\right\}}{p\left\{Y_{0^{t}} \mid \cdot H_{-1}\right\}} \quad(i=0,1, \cdots, k)
$$

と定義すれば，これは (3) 式を用いて (5.a)，(5.b) 式を

$$
\begin{array}{ll}
H_{i}: d y(\tau)=\left[\tilde{s}_{i}(\tau)+B y(\tau)\right] d \tau+d v(\tau) & \text { (8. a ) } \\
H_{-1}: d y(\tau)=B y(\tau) d \tau+d v(\tau) & \text { (8. b) }
\end{array}
$$

のように改めることによって,

$$
\begin{aligned}
& d \Lambda\left(t, t_{i}\right)=\Lambda\left(t, t_{i}\right) \tilde{s}_{i}(t) R^{-1}\{d y(t)-B y(t) d t\} \\
& \Lambda\left(t_{i}, t_{i}\right)=1
\end{aligned}
$$

の解として得られる. ここに

$$
\tilde{s}_{i}(t) \triangleq \dot{s}_{i}(t)-B s_{i}(t)
$$

であり，（9)式の導出は文献 2 の定理 1 の証明之同様 にしてできるので省略する。（9)式より対数尤度比関 数は

$$
\begin{aligned}
\ln \Lambda\left(t, t_{i}\right)= & \int_{t_{i}}^{t} \tilde{s}_{i}(\sigma) R^{-1} d y(\sigma) \\
& -\int_{t_{i}}^{t} \tilde{s}_{i}(\sigma) R^{-1}\left[B y(\sigma)+\frac{1}{2} \tilde{s}_{i}(\sigma)\right] d \sigma
\end{aligned}
$$

となる ${ }^{2)}$. Fig. 2 は対数尤度比関数. $\left\{\ln \Lambda\left(t, t_{i}\right) ; i=\right.$ $0,1, \cdots, k\}$ の計算法を概念的に示したむのである. 観 測データ $Y_{0}{ }^{t}$ を取得しながら (11) 式を用いて $\{\ln \Lambda$ $\left.\left(t, t_{i}\right)\right\}$ を計算し，乙れらを予め設定された閾值 $\rho_{0}$ と 比較する．（i )むし $\rho_{0}$ を越える $\ln \Lambda\left(t, t_{i}\right)$ がなけれ ば, 仮説 $H_{-1}$ を受容し, 現在時刻 $t$ までに信号は存 在しないと決定し，さらに新しい観測データを取得し 、て同じ手順を繰り返す．（ii）むし $\rho_{0}$ を越える $\ln \Lambda$ $\left(t, t_{i}\right)$ が存在すれば，その時点において（これを以後 決定時刻 $t_{D}$ と呼ぶ）仮説 $H_{i}$ を受容し，信号は $\tau_{0}$ $(\omega)=t_{i}$ から存在すると決定する.ただし上の手順にお いて, $\rho_{0}$ を越える $\ln \Lambda\left(t, t_{i}\right)$ が複数個存在すれば,最 大尤度原理に基づいて, それらの中の最大の $\ln \Lambda\left(t, t_{i}\right)$ を与える仮説を受容するすのとする.

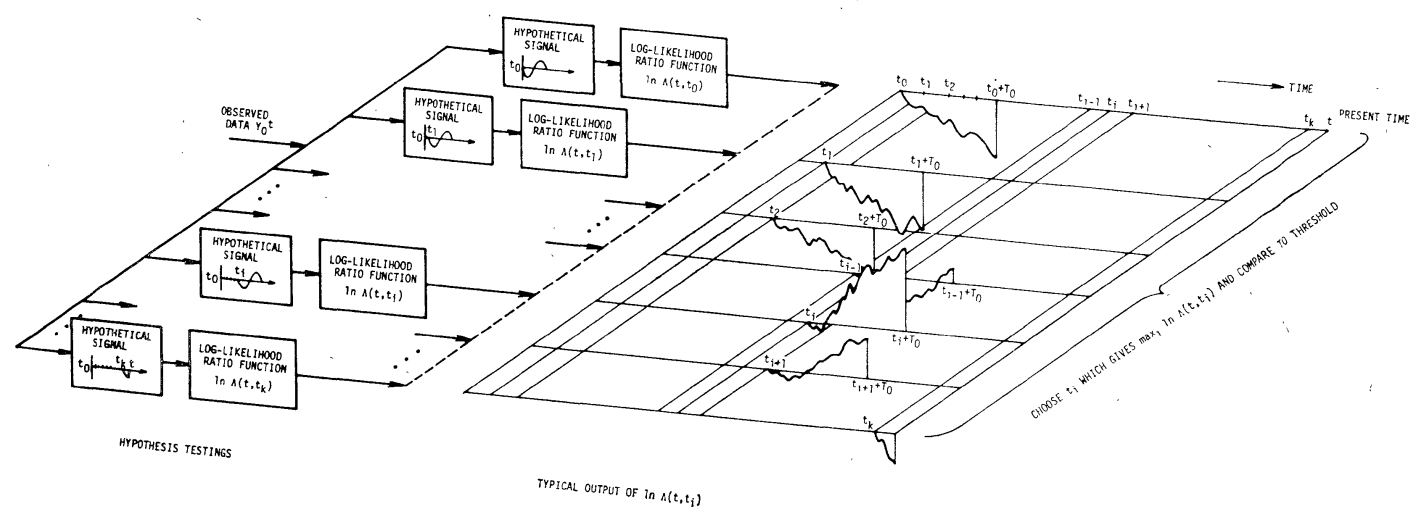

Fig. 2 System for detecting signal with unknown initial time 
こてで述べた方法では, 時間 $t$ の経過とともに仮説 $H_{i}$ の個数む増加するが，検定すべき信号波形の周期 T0 が既知であるととに留意すれば，実際上の計算で は時間区間 $\left[t-T_{0}, t\right]$ 内に含ま机る $\left\{t_{i}\right\}$ 亿対する $\ln \Lambda\left(t, t_{i}\right)$ のみを計算す机ばよいことになる．本節で 述べた方法により，一応信号の存在確認と信号の初期 時刻の推定は達成できるが，信号の早期検出という立 場からは何ら手段は講じられていない，本論文では， 早期信号検出を実行するために閾值 $\rho_{0}^{\prime}$ の設定に着目 することにした.

\section{2 闒値の設定}

対数尤度比関数 $\ln \Lambda\left(t, t_{i}\right)$ の平均過程は, $\tau_{0}(\omega)=t_{i}$ という仮説 $H_{i}$ のむとでは

$$
\begin{aligned}
\lambda_{i}\left(t, t_{i}\right) & \triangleq \mathcal{E}\left\{\ln \Lambda\left(t, t_{i}\right) \mid H_{i}\right\} \\
& =\frac{1}{2} \int_{t_{i}}^{t} \tilde{s}_{i}{ }^{2}(\sigma) R^{-1} \dot{d} \sigma
\end{aligned}
$$

となり，また一方，仮説 $H_{-1}$ のもとでは，

$$
\begin{aligned}
\bar{\lambda}_{i}\left(t, t_{i}\right) & \triangleq \mathcal{E}\left\{\ln \Lambda\left(t, t_{i}\right) \mid H_{-1}\right\} \\
& =-\frac{1}{2} \int_{t_{i}}^{t} \tilde{s}_{i}{ }^{2}(\sigma) R^{-1} d \sigma
\end{aligned}
$$

となる。乙こに $\mathcal{E}\{\cdot \mid *\}$ は*の条件付期待值演算子 である. $\lambda_{i}$ 打よび $\bar{\lambda}_{i}$ を図示すれば Fig. 3 のように なる.すなおち, 対数尤度比関数 $\ln \Lambda\left(t, t_{i}\right)$ の平均過 程は, 仮説 $H_{i}$ のもとでは単調増加し, また $H_{-1}$ の あとでは単調減少するととから，信号の有無によって 顕著に異なった様相を呈する，乙の特性に着目して， 閾值 $\rho_{0}$ をつぎのように設定することにする，てのと き，むし時刻 $t_{i}$ から信号が存在するすのとすれば, $\delta 0$ 時間経過した時刻にその存在を確認したいという 目的のために，閾値を

$$
\rho_{0}\left(\delta_{0}\right)=\lambda_{i}\left(t_{i}+\delta_{0}, t_{i}\right)
$$

之設定すれば, 従来 $\left(t_{i}+T_{0}\right)$ 時刻に括いて信号検出 を実現していた（Fig. 1) のを，それよりむ $\left(T_{0}-\delta_{0}\right)$

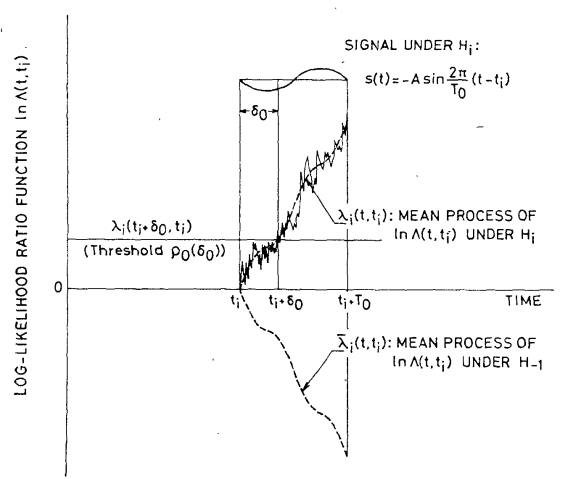

Fig. 3 Concept of determination of the threshold for the early decision-making
Fig. 4 Threshold $\rho_{0}\left(\delta_{0}\right) \quad$ vs. $\delta_{0} / T_{0}$ $\left(B=-0.008, \quad T_{0}\right.$ $=2$ )

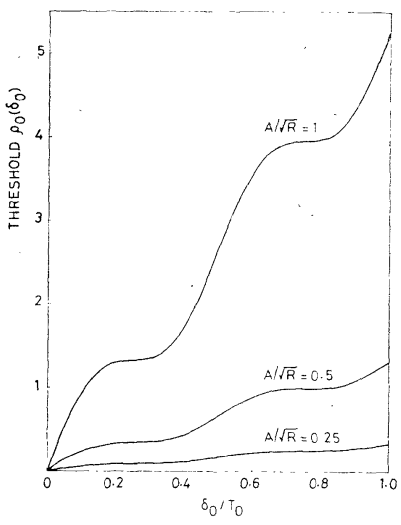

時間早い信号検出実現の可能性が期待できることにな る. このように設定した閾値は明らかに方。の関数と なるので，以後 $\rho_{0}(\delta 0)$ と表記するととにする.

$$
\begin{aligned}
& \text { (12), (14)式より } \\
& \rho_{0}\left(\delta_{0}\right)=\frac{1}{2} \int_{t_{i}}^{t_{i}+\delta_{0}} \tilde{s}_{i}{ }^{2}(\sigma) R^{-1} d \sigma \\
& =\left(\frac{A}{\sqrt{R}}\right)^{2}\left[\left(\frac{\pi^{2}}{T_{0}{ }^{2}}+\frac{B^{2}}{4}\right) \delta_{0}+\frac{1}{4}\left(\frac{\pi}{T_{0}}-\frac{B^{2} T_{0}}{4 \pi}\right)\right. \\
& \left.\cdot \sin \frac{4 \pi}{T_{0}} \delta_{0}+\frac{B}{4}\left(\cos \frac{4 \pi}{T_{0}} \delta_{0}-1\right)\right]
\end{aligned}
$$

となり， $A / V \bar{R}$ (これは信号の $\mathrm{S} / \mathrm{N}$ 比に相当する) をパラメータとして図示したのが Fig. 4 である.

Fig. 4 よりわかることは，信号の検出時間を短縮した り，また $\mathrm{S} / \mathrm{N}$ 比の低い悪条件のむとで信号検出を実 行しようとすれば，閾値を小さくしなければならない ということである.

さて，(15)式で設定される閾值を用いて信号検出を 実行しょう之すれば，従来信号波形の通過完了時にお いて決定をしていた信号検出よりむ，より大きな危険 率を伴うのの明白である，そこで以下では，仮説 $H_{-1}$ が真であるときに，時刻 $t=t_{i}+\delta_{0}$ において $H_{i}$ を受 容する確率を第 1 種誤り確率 $P_{F}(\delta 0)$ と定義し，乙れ を求めるととにする。いま

$$
\mu\left(t, t_{i}\right) \triangleq \ln \Lambda\left(t, t_{i}\right)
$$

と定義すれば，乙れは(11)式より

$$
\begin{aligned}
& \left.d \mu\left(t, t_{i}\right)=\tilde{s}_{i}(t) R^{-1}\left\{d y(t)-\left[B y(t)+\frac{1}{2} \tilde{s}_{i}(t)\right] d t\right\}\right\} \\
& \mu\left(t_{i}, t_{i}\right)=0
\end{aligned}
$$

という確率微分方程式の解であるから, 仮説 $H_{-1}$ の あとでのその確率密度関数はつぎのように与えられ る.

$$
p\left\{t, \mu \mid H_{-1}\right\}=c_{t} \exp \left\{-\frac{1}{2 \sigma_{\mu}{ }^{2}}\left(\mu-\bar{\lambda}_{i}\right)^{2}\right\}
$$




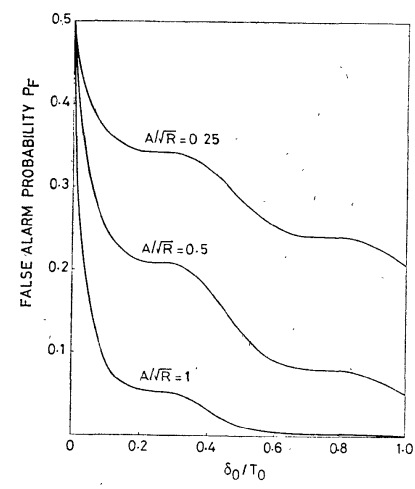

Fig. 5 False alarm probability $P_{F}$ vs. $\delta_{0} / T_{0}(B=-0.008$, $\left.T_{0}=2\right)$

ただし， $\quad \sigma_{\mu}{ }^{2}\left(t, t_{i}\right) \triangleq \operatorname{var}\left[\mu\left(t, t_{i}\right)\right] \equiv 2 \lambda_{i}\left(t, t_{i}\right), c_{t}=1 /$ $\sqrt{2 \pi} \sigma_{\mu}$ である.したがって，第 1 種誤り確率 $P_{F}\left(\delta_{0}\right)$ は, $t=t_{i}+\delta_{0}$ のとき $\bar{\lambda}_{i}\left(t_{i}+\delta_{0}, t_{i}\right)=-\lambda_{i}\left(t_{i}+\delta_{0}, t_{i}\right)=$ $-\rho_{0}\left(\delta_{0}\right), \sigma_{\mu}{ }^{2}\left(t_{i}+\delta_{0}, t_{i}\right)=2 \lambda_{i}\left(t_{i}+\delta_{0}, t_{i}\right)=2 \rho_{0}\left(\delta_{0}\right)$ の関係 に留意すれば $(18)$ 式より

$$
\begin{aligned}
P_{F}\left(\delta_{0}\right) & =\int_{\rho_{0}\left(\delta_{0}\right)}^{\infty} p\left\{t_{i}+\delta_{0}, \mu \mid H_{-1}\right\} d \mu \\
& =\frac{1}{2} \operatorname{erfc}\left(\sqrt{\rho_{0}\left(\delta_{0}\right)}\right)
\end{aligned}
$$

となる. ここに, $\operatorname{erfc}(z) \triangleq(2 / \sqrt{\pi}) \int_{z}^{\infty} \exp \left\{-\xi^{2}\right\} d \xi$

という余誤差関数である. Fig. 5 は $P_{F}\left(\delta_{0}\right)$ を図示し たものである．図より， $\delta_{0} / T_{0}$ を小さくすればするほ ご，また S/N 比が小さくなればなるほぎ，第 1 種誤 り確率は高くなるととがわかる。

Figs. 4, 5 より, 早期信号検出を目指そうとすれば, 閾値を下げればよいが，それに応じて危険率は高まる ことがうかがわれる，むし信号検出に際して， $P_{F}\left(\delta_{0}\right)$ をある一定に保ちたいならば，Fig. 5 より与えられた $P_{F}\left(\delta_{0}\right)$ に対して $\delta_{0} / T_{0}$ を求め，その $\delta_{0} / T_{0}$ に対する 閾值 $\rho_{0}\left(\delta_{0}\right)$ を Fig. 4 より求めればよい.

\section{3. 信号検出とその検出法の評価}

\section{1 信号検出に対する決定則}

信号波形の検出に対する決定則を 2.1 節において述 ベた 2 段階の手順により行う.

<信号検出に対する決定則 $>$ 時刻 $t$ （ただし $t_{k}<t$ $\leq t_{k+1}$ とする）までに取得された観測データ $Y_{0}{ }^{t}=$ $\{y(\tau), 0 \leq \tau \leq t\}$ に基づいて，(11)式により詨数尤度比 関数 $\ln \Lambda\left(t, t_{i}\right)$ を， $i=0,1, \cdots, k$ なるすべての $i$ につ いて計算し,

（i）もし $\max _{i} \ln \Lambda\left(t, t_{i}\right)<\rho_{0}\left(\delta_{0}\right)$ ならば，仮説 $H_{-1}$ を受容する.

（ii）むし（ｉ）において $H-1$ が萧却されるならば,
そのとき $\max _{i} \ln \Lambda\left(t, t_{i}\right)$ 亿対応する仮説 $H_{i}$ を受容 し，信号は $\tau_{0}(\omega)=t_{i}$ 加ら存在すると決定する。

決定時刻 $t=t_{D}$ において，たとえば仮説 $H_{i}$ が真で あると決定されたならば，その他の仮説 $\left\{H_{\nu} ; \nu=0\right.$, $1, \cdots ; \nu \neq i\}$ はすべて䢂却される. よって $t_{D}$ を数学的 に表記すれば， $t_{D}=\min \left\{t: \max _{i} \ln \Lambda\left(t, t_{i}\right) \geq \rho_{0}\left(\delta_{0}\right)\right\}$ となる。

\section{2 信号検出の特性評価}

3.1 節で述べた決定則によれば，仮説 $H_{i}$ が真であ るとき，時刻 $t=t_{i}+\delta_{0}$ において信号検出が期待でき

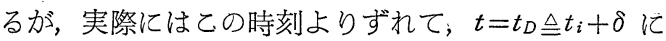
おいて信号波形の存在が確認される。したがって，決 定を下した後の危険率を再吟味する必要が生じてく る.そこで，実際決定を下した後の第 1 種誤り確率を $P_{A F}$ として定義すれば，乙れは当然実際に信号検出に 要した時間 $\delta\left(=t_{D}-t_{i}\right)$ の関数となり，(18) 式よりつ ぎのように評価される.

$$
\begin{aligned}
P_{A F}(\delta ; \delta 0) & =\int_{\rho_{0}\left(\delta_{0}\right)}^{\infty} p\left\{t_{D_{i}} \mu \mid H_{-1}\right\} d \mu \\
& =\frac{1}{2} \operatorname{erfc}\left\{\frac{\rho_{0}\left(\delta_{0}\right)+\lambda_{i}\left(t_{i}+\delta, t_{i}\right)}{2 \sqrt{\lambda_{i}\left(t_{i}+\delta, t_{i}\right)}}\right\}
\end{aligned}
$$

ここで, $\bar{\lambda}_{i}\left(t_{D}, t_{i}\right) \equiv-\lambda_{i}\left(t_{D}, t_{i}\right), \sigma_{\mu}{ }^{2}\left(t_{D}, t_{i}\right) \equiv 2 \lambda_{i}\left(t_{D}, t_{i}\right)$ の関係を用いた． Fig. 6 は $P_{A F}$ を $\mathrm{S} / \mathrm{N}$ 比 $A / V \bar{R}$ および $\delta_{0} / T_{0}$ をパラメータとして図示したすのであ る. この図によれば, $P_{A F}\left(\delta ; \delta_{0}\right)$ は $\delta=\delta_{0}$ のとき最 大となり, しかむ $(19),(20)$ 式より $P_{A F}\left(\delta_{0} ; \delta_{0}\right) \equiv P_{F}$ $\left(\delta_{0}\right)$ であることから, $P_{A F}\left(\delta ; \delta_{0}\right) \leq P_{F}\left(\delta_{0}\right)$ の関係が得 られる: このことから，Figs. 4,5 を用いて $P_{F}\left(\delta_{0}\right)$ を 一定に保つように閾值 $\rho_{0}\left(\delta_{0}\right)$ を設定して屯, 実際上 その危険率は，常に $P_{F}\left(\delta_{0}\right)$ 以下におさえられること が保証されていることがわかる。

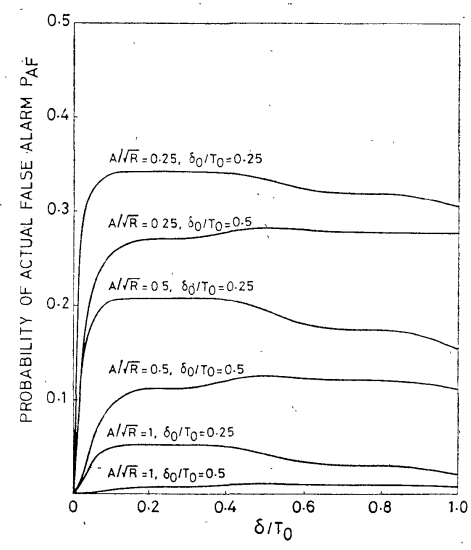

Fig. 6 Probability of actual false alarm $P_{A F}\left(\delta ; \delta_{0}\right)$ 


\section{4. シミュレーション例}

\section{1 ディジタル・シミュレーション}

ディジタル・シミュレーションでは，信号の周期は $T_{0}=2$ とし, 未知初期時刻 $\tau_{0}(\omega)$ を $\tau_{0}(\omega)=5$ 亿設定 した．またその他のパラメータとして， $A=0.2, B=$ $-0.008, R=0.15$ とし，時間差分を $d t=0.05$ とし た. Fig. 7(a) は計算機により創成して得られた観 測過程の見本値である. 手順はつぎのようである.

1) まず仮説 $\left\{H_{i} ; i=0,1, \cdots\right\}$ を設定する. シミュ レーションでは，仮説 $H_{i}$ 亿対応する離散時刻 $t_{i}$ は $\left\{t_{i}=i / 10 ; i=0,1, \cdots\right\}$ とした. $\tau_{0}(\omega)$ の真值は $\tau_{0}(\omega)$ $=5$ と設定されているので，仮説 $H_{50}$ が真の仮説 と なる.

2) つぎに，任意に $\delta_{0}$ を設定し，乙の $\delta_{0}$ に対応す 万閾值 $\rho_{0}\left(\delta_{0}\right)$ を Fig. 4 または (15) 式を用いて求め る. シミュレーションでは, $\delta_{0}=T_{0} / 4, T_{0} / 2$ および $T_{0}$ の 3 通りの場合を考察した. $\rho_{0}\left(T_{0} / 4\right)=0.33$, $\rho_{0}\left(T_{0} / 2\right)=0.66$ また $\rho_{0}\left(T_{0}\right)=1.32$ となる.

3) 時刻 $t$ までの観測データ $Y_{0}{ }^{t}$ を用いて, (11) 式 より与えられる対数无度比関数 $\ln \Lambda\left(t, t_{i}\right)(i=0,1, \cdots)$ を計算し，3.1 節において述べた信号検出に対する決 定則に基づいて仮説検定を実行する。

Fig. 7 (b) は, $\ln \Lambda\left(t, t_{i}\right)$-過程を示したむのである が，乙こでは四つの仮説 $H_{15}, H_{45}, H_{50}$ おおよび $H_{55}$ に

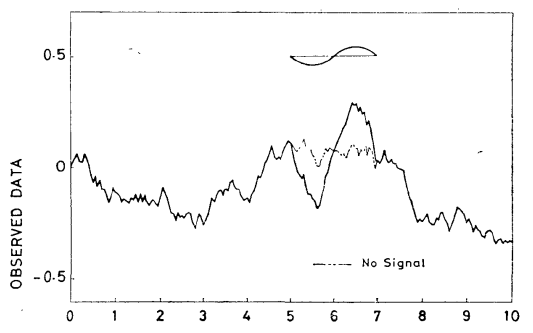

(a) Observed data

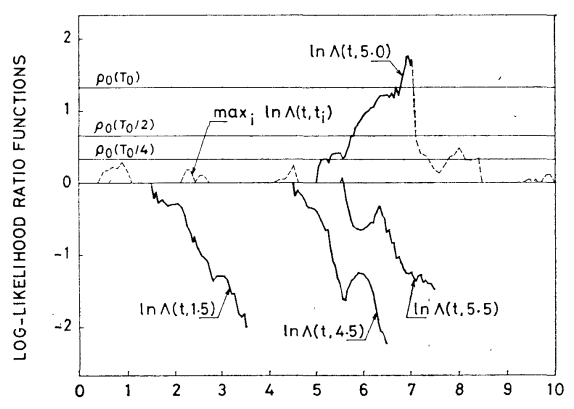

(b) $\ln \Lambda\left(t, t_{i}\right)$-runs

Fig. 7 Simulation results of $\ln \Lambda\left(t, t_{i}\right)$-runs $(A / \sqrt{R}=0.5)$
対応する見本過程 $\ln \Lambda(t, 1.5), \ln \Lambda(t, 4.5), \ln \Lambda(t$, 5.0) および $\ln \Lambda(t, 5.5)$ のみを示した. 眓中の破線 は，時刻 $t$ 亿抢怕る $\left\{\ln \Lambda\left(t, t_{i}\right)\right\}$ の中の最大の值を示 したすのである．破線を辿ることにより，図から明ら かに，t=5.1 までは閾值，たとえば $\rho_{0}\left(T_{0} / 4\right)$ を越え る $\ln \Lambda\left(t, t_{i}\right)$ は存在しない. $t=5.1$ 亿なって初めて, $\ln \Lambda(t, 5.0)$ が $\rho_{0}\left(T_{0} / 4\right)$ を越えるととから， $t_{D}=5.1$ であり仮説 $H_{50}$ が受容され， $\tau_{0}(\omega)=5$ であると決定 される. したがって，いま $\tau 0(\omega)$ の真值が 5 であった ことから，本例においては真に正しく決定が下された ことになる．著者らの提案した従来の信号検出法 ${ }^{1), 2)}$ によれば，信号の終端時刻に扔いて信号の存在が確認 されていたから，決定を下すのに要した時間は $\delta=t_{D}$ $-t_{50}=0.1\left(\delta / T_{0}=0.05\right)$ すなわち $0.95 T_{0}$ 時間早く 信号検出が行われているととになる.

閾值 $\rho_{0}\left(T_{0} / 4\right)$ とした時に下された決定に対して, 第 1 種誤り確率 $P_{A F}$ は Fig. 6 亿より約 $18 \%$ であ る. 閾值を $\rho_{0}\left(T_{0} / 2\right)=0.66$ としてむ $\rho_{0}\left(T_{0} / 4\right)=0.33$ に対して受容された仮説と同じ仮説 $H_{50}$ が受容され るが，乙の場合には $t_{D}=5.85$ であり， $\rho_{0}\left(T_{0} / 4\right)$ の場 合よりも大幅に決定時刻が遅れるととが Fig. 7(b) よりわかる。

\section{2 実データによるシミュレーション}

Fig. 8（a）は（測定器により）実際に記録された 不規則雑音 $\eta(t)$-過程の一部を示したすのである. こ のデータは文献 2 にあ使用されたあのであるが，本論 文でも提案した早期検出法が実データに対しても有効 かどうかを検証するために再び使用された．ての雑音 過程の頻度分布求よび自己相関関数を求めることによ り, $\eta(t)$ は正規性有色雑音過程であり, (3)式によっ てモデリングできるてとが確認されている2). しかし (3)式に打けるパラメータ $B$ 扰よび $R$ の真值は未知 であり，信号検出にあたってはてれらの推定值が必要 となる. 未知パラメータの同定を伴う信号検出法は文 献 2 亿捄いて述べたが，乙こでもその方法を適用する 乙とにする. 未知パラメータ $\{B, R\}$ の推定值を $\hat{B}(t)$ $\triangleq \mathcal{E}\left\{B \mid Y_{0^{t}}\right\}, \hat{R}(t) \triangleq \mathcal{E}\left\{R \mid Y_{0}{ }^{t}\right\}$ 乙し, (5. a ), (5. b) 式によって記述される仮説 $\left(H_{i}, H_{-1}\right)$ の代わりに

$$
\begin{aligned}
& \hat{H}_{i}: y(\tau)=s_{i}(\tau)+\hat{\eta}(\tau) \\
& \hat{H}_{-1}: y(\tau)=\hat{\eta}(\tau)
\end{aligned}
$$

を考える.ただし $\hat{\eta}(\tau) は$

$$
d \hat{\eta}(\tau)=\hat{B}(\tau) \hat{\eta}(\tau) d \tau+d \hat{v}(\tau), \quad \hat{\eta}(0)=0
$$

によって記述される過程であり, $\hat{v}(\tau)$ は $\hat{R}(\tau)$ という 分散をむつ Brown 運動過程である。(21. a ), (21. b ) 式の両辺の時間増分をとり，(22)式を用い,ささら新 し< 


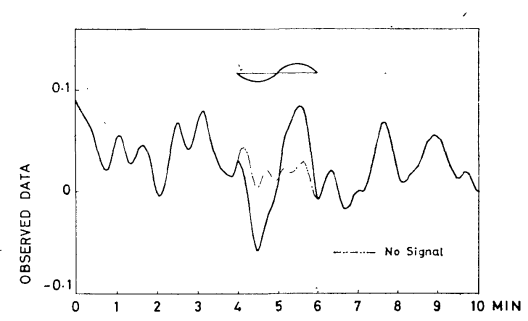

(a) Observed data

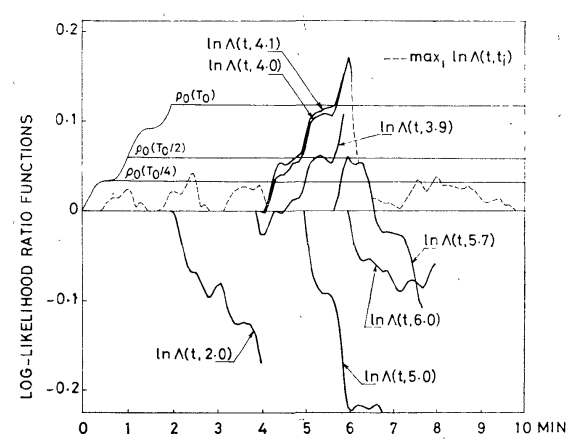

(b) $\ln \Lambda\left(t, t_{i}\right)$-runs

Fig. 8 Results of $\ln \Lambda\left(t, t_{i}\right)$-runs for real observed data

$$
d \tilde{y}(\tau) \triangleq d y(\tau)-\hat{B}(\tau) y(\tau) d \tau
$$

なる $\tilde{y}(\tau)$-過程を導入すれば, (21. a ), (21. b)によっ て記述される仮説検定 $\left(\hat{H}_{i}, \hat{H}_{-1}\right)$ はつぎの仮説検定

$$
\begin{aligned}
& \tilde{H}_{i}: d \tilde{y}(\tau)=\hat{s}_{i}(\tau) d \tau+d \hat{v}(\tau) \\
& \tilde{H}_{-1}: d \tilde{y}(\tau)=d \hat{v}(\tau)
\end{aligned}
$$

に等価変換できる、ただし

$$
\hat{s}_{i}(\tau) \triangleq \dot{s}_{i}(\tau)-\hat{B}(\tau) s_{i}(\tau)
$$

である．とのように変換するととによって，(11)式に 対応する対数尤度比関数はつぎのようになる2).

$$
\begin{aligned}
& \ln \Lambda\left(t, t_{i}\right)=\int_{t_{i}}^{t} \hat{s}_{i}(\sigma) \hat{R}^{-1}(\sigma) d y(\sigma) \\
& \quad-\int_{t_{i}}^{t} \hat{s}_{i}(\sigma) \hat{R}^{-1}(\sigma)\left[\hat{B}(\sigma) y(\sigma)+\frac{1}{2} \hat{s}_{i}(\sigma)\right] d \sigma
\end{aligned}
$$

実験では，信号 $s(t, \cdot)$ は Fig. 8(a) に示すように $4[\mathrm{~min}]$ から 6[min] の間に隠されており， $T_{0}=2$ [min], $A=0.06$ であり, また $\left\{t_{i}=i / 10[\mathrm{~min}] ; i=0\right.$, $1, \cdots\}$ とした. 未知パラメータ $\{B, R\}$ の推定には Bayes 推定值を用い2)，閾値の設定にあたっては(15. a)式を考慮に入れて

$$
\rho_{0}\left(\delta_{0} ; t_{i}\right)=\frac{1}{2} \int_{t_{i}}^{t_{i}+\delta_{0}} \hat{s}_{i}{ }^{2}(\sigma) \hat{R}^{-1}(\sigma) d \sigma
$$

とした. ここで閾值 $\rho_{0}\left(\delta_{0} ; t_{i}\right)$ は, $\hat{R}(t)$ と $\hat{B}(t)$ が確 率過程となるため, オンラインで計算しなければなら ず，また $t_{i}$ に依存してくる. Fig. $8(\mathrm{~b})$ は $\ln \Lambda(t$, $\left.t_{i}\right)$ 一過程の中の代表的な見本過程を示したものであ る. 破線で示された $\max _{i} \ln \Lambda\left(t, t_{i}\right)$ の軌跡を辿るこ とによって，むし $\delta_{0}=T_{0} / 4$ と設定するならば約 2.7 [min] 付近で閾值を越える対数尤度比関数が存在し, 信号検出は不首尾に終る. しかし $\delta_{0}=T_{0} / 2$ と選べば, $\ln \Lambda(t, 4.1)$ がいち早く閾值 $\rho_{0}\left(T_{0} / 2\right)$ を越えることか ら仮説 $H_{41}$ が受容され（真の仮説は $\left.H_{40}\right), \tau_{0}(\omega)=$ 4.1 [min] と決定される. またそのときの決定時刻は $t_{D}=4.3[\mathrm{~min}]$ であるから非常にうまく早期検出され ているととがわかる.

\section{5. 結 言}

本論文に执いて，オンライン処理を指向してその初 期時刻が不確定である 1 周期正弦波信号に対する早期 信号検出法を提案した. その手法の鍵となるのは, (4) 式で記述される 2 值複合仮説検定問題を(5)式の ように多值単純仮説検定問題に変換し, 信号の未知不 確定初期時刻の同定と検出を同時に実行し, 信号存在 の早期決定を閾值の設定法に帰着させたととである. ここに提案した早期信号検出法は, 著者らが提案した 従来の方法 ${ }^{1}{ }^{2}$ (2) 飞比して, 十分早期の信号検出が期待 できる. しかも信号の初期時刻の同定む可能であり, 工学的にも交通制御システム, 通信システムなどの分 野においても有用であると考えられる.なお本研究 は, 昭和 54 年度文部省特定研究費の補助を得て行わ れたととを記し，謝意を表する。

\section{参考 文 献}

1) Y. Sunahara: On a Method of Signal Detection by Using the Nonlinear Estimation Theory, Proc. 3rd Symp. on Nonlinear Estimation Theory and Its Applications, San Diego, Calif., 216/223, Sep. (1973)

2) 砂原, 大住, 檀上: 未知統計量をむつ有色雑音に埋もれ た信号の検定，計測自動制御学会論文集，15-4, 478/485 (1979)

3) H. L. Van Trees: Detection, Estimation, Modulation Theory, Part I, John Wiley, New York (1968) 